\title{
The context of fisheries subsidies within the trade agenda - developments to date and the WTO 2017 Ministerial Conference in Buenos Aires
}

\section{Subsídios à pesca na agenda comercial - histórico das negociações e a Conferência Ministerial 2017 da OMC em Buenos Aires}

\author{
Bruno Capuzzi (iD \\ Universidade de Torino \\ E-mail: bruno.capuzzi0@gmail.com
}

\begin{abstract}
Since the 1990s, discussions aiming to reduce and to eliminate certain harmful fisheries subsidies have been taking place at multilateral forums. If the trade distorting effects and the environmental threats of these subsidies are no longer questioned, clear rules on definitions and determination of these practices have not been set giving divergences of approaches and interests of member States of the multilateral trade system. With the adoption of the Sustainable Development Goals in 2015, within the scope of the United Nations, countries were firstly challenged with a clear target to prohibit and to eliminate types of harmful subsidies. This article covers the main developments on the thematic based on official and public documents since the creation of the World Trade Organization (WTO) and tackle the major proposals tabled in anticipation to the Organization's $11^{\text {th }}$ Ministerial Conference, in Buenos Aires in 2017, and its progresses until beginning of 2019. It also concludes that lack of technical cooperation and convergent interest made impossible for the Conference to drawn conclusive line under any sort of definition.
\end{abstract}

Keywords: Fisheries subsidies; WTO; IUU fishing; overfished stocks; Buenos Aires Ministerial Conference.

Resumo: Desde os anos 90, os fóruns multilaterais de negociações têm sido palco de discussões sobre a redução e eliminação de certos subsídios à pesca. O reconhecimento das distorções ao comércio e dos efeitos ambientais causados por este tipo de subsídio não foram, contudo, suficientes para as partes acordarem sobre regras de definições e determinações de subsídios. Com a adoção dos Objetivos de Desenvolvimento Sustentável (ODS) em 2015, no âmbito das Nações Unidas, uma meta de proibição e eliminação de subsídios danosos foi pela primeira vez apresentada aos países. Este artigo descreve as principais negociações e proposições sobre subsídios à pesca com base em documentos oficiais e públicos desde a criação da Organização Mundial do Comércio (OMC), passando pela falta de acordo na $11^{\text {a }}$ Conferência Ministerial desta Organização em Buenos Aires (2017), e desdobramentos até início de 2019.

Palavras-Chave: Subsídios à pesca; OMC; Pesca Ilegal, Irregular e Não-Reportada; estoques de pesca sobre utilizados; Conferência Ministerial de Buenos Aires. 
CAPUZZI, Bruno. The context of fisheries subsidies within the trade agenda-developments to date and the WTO 2017 Ministerial Conference in Buenos Aires.

\section{Introduction}

The topic of fisheries subsidies has been considered one of the unfinished business form the creation of the World Trade Organization (WTO) as, differently to other fishing topics, it was set under the prerogative of the Organization's technical apparatus in detriment of fishing and food bodies of the United Nations System, such as the Food and Agriculture Organization (FAO). Discussions aiming the reduction and the elimination of certain fisheries subsidies date back from the 1990s when the issue was brought to the Committee of Trade and Environment (CTE) of the World Trade Organization (WTO). Since then, their trade distorting effects and environmental drawbacks have been recognized. However, it was not before the adoption of the 2030 Agenda and the setting of the Sustainable Development Goals (SDGs), in 2015, that countries were challenged with a clear goal and target on the subject. Target 6 of the SDG 14 demands countries to prohibit or eliminate certain types of fisheries subsidies by 2030. After this introductory part, this document presents the result of a descriptive analysis of official documents and positions from member States within the framework of the World Trade Organization in respect to qualifying types of subsidies under existent agreements.

Subsidies that contribute to overcapacity and overfishing shall be prohibited while those linked to illegal, unreported and unregulated (IUU) fishing eliminated. Furthermore, countries shall refrain themselves from introducing new alike subsidies. Member States expected Buenos Aires $\left(\mathrm{MC} 11^{1}\right)$ to be a "housekeeping" conference where positions and statements are reiterated without the necessity of structural changes. This was the exact pattern followed in almost each and very topic, including fisheries subsides. Talks under the Negotiating Group on Rules delivered a simple commitment to fulfil SDG 14.6 by 2020 passing through an agreement on the $\mathrm{MC}^{2} 2^{2}$, in Jamaica in 2019.

The provisions of SDG 14.6 are consistent with the principle of special and differentiated treatment for developing and Least Developed Countries in the multilateral system of trade ${ }^{3}$, and member States accordingly agreed in observing such treatment in the agreement to come. Such preference is set under the recognition of trade fragilities existent in these countries, and within

\footnotetext{
${ }^{1}$ WTO 11th Ministerial Conference, Buenos Aires 2017.

${ }^{2}$ WTO $12^{\text {th }}$ Ministerial Conference, Jamaica 2019.

${ }^{3}$ https://www.wto.org/english/tratop_e/devel_e/dev_special_differential_provisions_e.htm
}

Revista Brasileira de Políticas Públicas e Internacionais, v.4, n.1, julho/2019, pp. 48-57. 
CAPUZZI, Bruno. The context of fisheries subsidies within the trade agenda-developments to date and the WTO 2017 Ministerial Conference in Buenos Aires.

the specific case, it acknowledges the role played by fish products in their economies. To illustrate this, $56 \%$ of world`s total fish exports are registered by developing and Least Developed Countries (LDCs) ${ }^{4}$.

Small Islands Developing States $\left(\operatorname{SIDS}^{5}\right)$ and LDCs are especially dependent on marine resources, representing, respectively, $7 \%$ and 1,5\% of world`s total fish exports. This dependency aggravates the dangers caused by trade distortions. Under general economic theory, subsidies can cause one or more of the following impacts on trade: i) distortions in the local market of member caused by subsidized imports; ii) distortions on the export markets caused by subsided exports from a third country; iii) distortions on partner`s export markets caused by subsidized local supply. Remarkably, the preluded distortions affect markets not just in quantum but also by diminishing prices (supply side effects) lowering income levels. This movement undercuts important portions of income harming more severely artisanal fisheries and local communities in SIDS and LDCs.

Recognizing the prominence of the topic and enjoying the momentum of the $11^{\text {th }}$ Ministerial Conference of the WTO the next two sections of this paper will elaborate, first, on the negotiations involving fisheries subsidies within the WTO. The following section will tackle recent developments including seven proposals tabled at the Negotiating Group on Rules (NGR) in a failed attempt to pave the road for an agreement in Buenos Aires and my subsidy further talks.

\section{The WTO and fisheries subsidies}

Before the creation of the WTO in 1995 the international trade system lacked a body of law enforcement and the Organization`s Dispute Settlement Body (DSB) ${ }^{6}$ doted the system with a set of agreed rules augmenting predictability on trade practices and remedies. Therefore, the

\footnotetext{
${ }^{4}$ The category of Least Developed Countries (LDCs) is given by the United Nations to those low-income countries facing high vulnerabilities to economic and environmental shocks. (https://www.un.org/development/desa/dpad/least-developed-country-category.html, accessed on 10 ${ }^{\text {th }}$ June 2018)

5 The United Nations Conference on Environment and Development (UNCED), Rio de Janeiro 1992, officially recognize a distinct group of countries as Small Island Developing States (SIDS) who faces specific social, economic and environmental vulnerabilities due to their geographical and economic contexts. (http://unohrlls.org/about-sids/ accessed on $10^{\text {th }}$ June 2018)

${ }^{6}$ More in https://www.wto.org/english/tratop_e/dispu_e/dsu_e.htm
}

Revista Brasileira de Políticas Públicas e Internacionais, v.4, n.1, julho/2019, pp. 48-57. 
CAPUZZI, Bruno. The context of fisheries subsidies within the trade agenda-developments to date and the WTO 2017 Ministerial Conference in Buenos Aires.

allocation of subjects in ruling agreements within the WTO scope was central for future developments. If the Antidumping Agreement ${ }^{7}$ guides dumping responses, actions dealing with prohibited and actionable subsidies are guided by the Agreement on Subsidies and Countervailing Measures (SCM Agreement) ${ }^{8}$. It was during the Uruguay Round that fisheries subsidies were set outside the Agreement on Agriculture (AoA) to be subjected to the SCM Agreement. If the Agreement on Agriculture rules on differentiated and decreased commitments on subsidies for the sector ${ }^{9}$, fisheries subsidies, for being out of it, are ruled by the framework of the SCM Agreement and of the Dispute Settlement Body. Considering that other fish associated topics are dealt by agriculture forums ${ }^{10}$, the fact that fisheries subsidies were subjected to the WTO technical apparatus made the issue to be considered one of the "unfinished businesses" of the Uruguay Round ${ }^{11}$ at the same time they were part of the "new-issues" dominating significant part of the trade agenda.

The Committee on Trade and Environment (CTE) of the WTO opened in 1997 discussions on fisheries subsidies and its High-Level Symposium from 1999 collected submissions from member States concerned with subsidies` impacts. If in the former the Unites States $^{12}$ condemned the over usage of global marine resources and its trade distortions, in the later, Australia, Iceland, New Zealand, the Philippines and the Unites States deposited a joint statement urging members to progressively eliminate trade-distorting subsidies on fisheries ${ }^{13}$. Notwithstanding these efforts, the attempt to include these discussions as a vivid theme did not flourish given the frustrated expectations of the Seattle Ministerial Conference in 1999, which followed sound protests referenced as the Battle of Seattle ${ }^{14}$. In the current century, however, the identification of links from fisheries subsidies with the over-exploitation of marine resources and the recognition of the threats posed by them to national economies has made the issue a recurrent

\footnotetext{
${ }^{7}$ https://www.wto.org/english/docs_e/legal_e/19-adp.pdf

${ }^{8}$ https://www.wto.org/english/docs_e/legal_e/24-scm.pdf

9 Gareth Porter, "Fisheries Subsidies and Overfishing: Towards a Structured Discussion" (Geneva: UNEP, 2002), at 3-4.

${ }^{10}$ Such as the Food and Agriculture Organization (FAO) and the World Food Programme (WFP)

${ }^{11}$ The Uruguay Round (1986-1994)

${ }^{12}$ WTO Doc. No. WT/CTE/W/51, (19 May 1997). Accessed on 15/08/2017

${ }_{13}$ WTO Doc. No. WT/CTE/W/121 (28 June 1999), Annex 1. Accessed on 15/08/2017

${ }_{14}$ Margaret Levi; Gillian Murphy, "Coalitions of Contention: the case of the WTO Protests in Seattle" (Hoboken: Blackwell Publishing, 2006)
}

Revista Brasileira de Políticas Públicas e Internacionais, v.4, n.1, julho/2019, pp. 48-57. 
CAPUZZI, Bruno. The context of fisheries subsidies within the trade agenda-developments to date and the WTO 2017 Ministerial Conference in Buenos Aires.

topic in the global trade agenda. In Hong Kong $(2005)^{15}$ the necessity of prohibiting certain fisheries subsidies was reiterated and in Doha $(2001)^{16}$ negotiations were launched to improve disciples on these subsidies.

If in Doha ministers agreed to clarify and to improve WTO applicable rules to fisheries subsidies (as studies demonstrated environmental harms ${ }^{17}$ ), the conference`s vague mandate reflected in opposing interests and submissions from countries. The intention of agreeing upon a broad prohibition of subsidies related to trade-distortion, overcapacity and overfishing by the 'Friends of Fish'18 was slowed down the European Union, Japan, Taiwan and the Republic of Korea. In Hong Kong, an environmental mandate specifically called for the prohibition of subsidies that contribute to overcapacity and overfishing. Negotiations rounded over possible approaches to be followed. A 'top-down' proposal headed by the 'Friends of Fish' demanded an extensive list of prohibitions and improved fisheries management programmes. It was confronted by a ‘bottom-up' alternative tabled by a group led by Japan, Taiwan and the Republic of Korea ${ }^{19}$. The Chair of the Negotiating Group on Rules (NGR) deferred in 2007 a draft proposal containing the submission from the parts.

The 2007 draft prohibited, among other programmes, subsidies for capacity building (construction, modification and repair), transfers of vessels, operating costs, fishing-related port infrastructure, income and price support, IUU and activities on overexploited stocks ${ }^{20}$. Exceptions were listed for programmes targeting vessels` safety, sustainable practices, aquaculture, natural disasters and accounted for special and differentiated treatment for developing countries. Under the later, LDCs, artisanal and small-scale fisheries were excluded from the prohibitions. In addition, subsidies targeted to vessels' modification for operation within countries`exclusive economic zone (EEZ) were drafted outside of the prohibitions provided the

\footnotetext{
${ }^{15}$ WTO $6^{\text {th }}$ Ministerial Conference was held in Hong Kong, China in December 2005.

${ }^{16}$ WTO $4^{\text {th }}$ Ministerial Conference was held in Doha, Qatar in November 2001.

17 in https://www.wto.org/english/thewto_e/whatis_e/tif_e/doha1_e.htm. Accessed on 15/08/2017

${ }_{18}$ Friends of Fish (FoFs) is an informal coalition that seeks to reduce fisheries subsidies formed by Argentina, Australia, Chile, Colombia, Ecuador, Iceland, New Zealand, Norway, Pakistan, Peru and the United States.

${ }^{19}$ FAO: The State of World Fisheries and Aquaculture - 2016 in: BAHETY, S. MUKIIBI, J. WTO fisheries subsidies, 2017

${ }^{20} \underline{\text { TN/RL/W/213 }}$ (November 30, 2007). Accessed on 15/08/2017
}

Revista Brasileira de Políticas Públicas e Internacionais, v.4, n.1, julho/2019, pp. 48-57. 
CAPUZZI, Bruno. The context of fisheries subsidies within the trade agenda-developments to date and the WTO 2017 Ministerial Conference in Buenos Aires.

fishing activity is proven to observe sustainable levels ${ }^{21}$. This draft did not flourish to become an agreed text as many of its disciplines diverged countries`opinions and, by 2008, a second revisited version reflected a "bottom-up" approach in some disciplines and a "roadmap for discussions" in others enlisting questions to guide further negotiations.

In 2009 the "Friends of Fish" coalition submitted its view on the common responsibility shared by all countries towards the preservation of global resources pondering that special and differentiated treatments shall not jeopardize the ultimate objectives. Under this light, subsidies that contribute to IUU fishing were urged to be completely prohibited to all countries. Notwithstanding, the subsidies permitted under a special and differentiated treatment were claimed the possibility to be considered actionable under the SCM Agreement ${ }^{22}$. The United States, in 2010, pursued clarification on the definitions contained in the draft, such as "unequivocally overfished state" and "evidences of harm" in cases of overcapacity and overfishing. The FAO Code of Conduct for Responsible Fisheries was then referred by the US as a valid source to be used. ${ }^{23}$

Barbados on behalf of the Small Vulnerable Economies (SVEs) ${ }^{24}$ addressed concerns that, despite special and differentiated treatments, restrictions set upon vulnerable economies could threaten their development for their heavy dependency on fisheries and marine tourism. Arguing that these economies little affected the degradation of fish resources hence their limited scale and markets, a higher burden of responsibility should be put upon countries with long history of overcapacity and utilization of subsidies. SVEs` submission proposed to exclude from prohibitions developing countries with less than $0.1 \%$ of world's trade of non-agricultural $\operatorname{goods}^{25}$. In a later submission the group reiterated concerns over the importance of domestic policy space for small economies and recommended countries with less than $1 \%$ of global marine capture to be excluded from the prohibitions ${ }^{26}$. A joint proposal from Brazil, China, Ecuador,

${ }^{21}$ Idid

22 TN/RL/W/243 (7 October 2009). Accessed on 15/08/2017

23 TN/RL/GEN/165 (22 April 2010). Accessed on 15/08/2017s

${ }_{24}$ Mandated by the Paragraph 35 of the Doha Ministerial Declaration and the Paragraph 4 of the Hong Kong Ministerial Mandate, the WTO Work Programme on Small Economies recommend on trade-related measures to improve the integration of small economies into the multilateral trading system.

$25 \mathrm{TN} / \mathrm{RL} / \mathrm{W} / 242$ (7 October 2009). Accessed on 15/08/2017

26 TN/RL/GEN/162 (6 January 2010). Accessed on 16/08/2017

Revista Brasileira de Políticas Públicas e Internacionais, v.4, n.1, julho/2019, pp. 48-57. 
CAPUZZI, Bruno. The context of fisheries subsidies within the trade agenda-developments to date and the WTO 2017 Ministerial Conference in Buenos Aires.

Mexico and Venezuela from 2009 recognized small-scale and artisanal fisheries as crucial for a significant share of the world`s poorest population and asked for balanced provisions.

Another collective of emerging economies, namely Brazil, China, India and Mexico, proposed a socio-economic criterion to assist in the ruling over small and artisanal fisheries, and condemned special and differentiated treatments applied to fisheries operating in domestic exclusive economic zones (EEZ's). Regarding high sea provisions, the group of countries challenged cost advantages enjoyed by developed economies and claimed the right to subsidy their fleet to compete with them ${ }^{27}$. The Republic of Korea in its submission from 2010 confronted the Negotiation Group of Rules (NGR) approach that pursued to list types of subsidies to be deemed as harmful and to be prohibited. The country's main point was centered in the importance of following the requirements of the SCM Agreement - the use, the specificity and the adverse effects cause by any alleged subsidy ${ }^{28}$.

The 2009-2011 period saw minimal convergence on key issues despite the generalized acceptance of the necessity of a fisheries regime to deal with exploited and overfished marine stocks. Countries did not, however, agree on the nature and scope of the rules of the regime, neither in the disciplines favoring developing countries. Therefore, on the absence of basis for a revised legal text, the Negotiation Group on Rules (NGR) reported in 2011 a summary of conclusions from the negotiations inviting member States to re-examine their positions in order to make progress. After non-relevance in Bali $(2013)^{29}$ the subject was issued again in Nairobi $(2015)^{30}$ when minimum convergence was reached. Recalling that the WTO $10^{\text {th }}$ Ministerial Conference (MC10) produced a bold agreement on the elimination of agriculture subsidies, the absence of the fisheries' sector in the Agreement on Agriculture still requires a sectorial agreement to deliberate on fisheries subsidies. Nevertheless, Nairobi was a forum where some issues were dealt and elaborated on, explicitly i) subsidies to vessels engaged in IUU and fishing in overexploited stocks; ii) transparency; iii) a refrain from the introduction of new subsidies; and iv) special and differentiated treatment ${ }^{31}$.

${ }^{27}$ TN/RL/GEN/163 (11 February 2010). Accessed on 16/08/2017

${ }_{28} \mathrm{TN/RL/W/245}$ (24 November 2009). Accessed on 16/08/2017

29 Available in https://www.wto.org/english/thewto_e/minist_e/mc9_e/mc9_e.htm. Accessed in 17/08/2017

${ }^{30}$ More in https://www.wto.org/english/thewto_e/minist_e/mc10_e/mc10_e.htm. Accessed in 17/08/2017

${ }^{31}$ UNCTAD, Trade and Environment Review 2016: Fish Trade, UNCTAD/DITC/TED/2016/3 (2016), at pp. 73-74

Revista Brasileira de Políticas Públicas e Internacionais, v.4, n.1, julho/2019, pp. 48-57. 
CAPUZZI, Bruno. The context of fisheries subsidies within the trade agenda-developments to date and the WTO 2017 Ministerial Conference in Buenos Aires.

\section{Recent development in preparation for Buenos Aires}

The adoption of the Sustainable Development Agenda in 2015 reignited countries interests towards pursing an agreed text on fisheries subsidies at the MC11 in Buenos Aires in December $2017^{32}$. Intending to guide the discussions and in light of the SDG target 14.6, Colombia, Iceland, New Zealand, Norway, Pakistan and Uruguay submitted, in 2016, a paper to the Negotiating Group on Rules (NGR ${ }^{33}$ commenting the countries`improvements in the sector, their respective subsidies`objectives and their main drivers for change. During the $1^{\text {st }}$ Ocean Conference held in the United Nations Headquarters in June 2017, 26 countries deposited voluntary commitments classified within the scope of target 14.6. Specifically, 11 of these countries deliberately committed with reducing or eliminating harmful fisheries subsidies ${ }^{34}$. More concretely, $7^{35}$ countries, or groups of countries, presented, by July 2017, textual proposals to the Negotiating Group on Rules (NGR) in expectations to fruit talks in preparation to the negotiations in Buenos Aires: i)New Zealand, Iceland and Pakistan; ii) European Union; iii) Indonesia; iv) ACP Group; v) Argentina, Colombia, Costa Rica, Panama, Peru and Uruguay; vi) LDC Group; vii) Norway.

The working document $274^{36}$ of the Negotiating Group on Rules (NGR) from November 2017 indicates an effort in accommodating the major contributions made by the seven proposals regarding the determination of IUU activity. This determination, as contained in the referred document, predicts a vessels' base approach following their identification by their flag State, by their subsidizing member, by a Regional Fishery Management Organization, by an international agreement or by an International Organization.

The elimination of subsidies for fishing activities in areas of overfished stocks is also subject of the working document 274. However, the non-convergence on the thematic in the

${ }^{32}$ https://www.wto.org/english/thewto_e/minist_e/mc11_e/mc11_e.htm

33 TN/RL/W/272/Rev.1 (27 May 2016). Accessed on 17/08/2017

34 Available in https://oceanconference.un.org/commitments/. Accessed in 17/08/2017

35 New Zealand, Iceland and Pakistan; the EU; Indonesia; the African, Caribbean and Pacific Group of States; Argentina, Colombia, Costa Rica, Panama, Peru, Uruguay, Least Developed Countries Group; and Norway. TN/RL/W/273 (28 July 2017). Accessed on 17/08/2017

36 TN/RL/W/274 (20 November 2017). Accessed on 17/08/

Revista Brasileira de Políticas Públicas e Internacionais, v.4, n.1, julho/2019, pp. 48-57. 
CAPUZZI, Bruno. The context of fisheries subsidies within the trade agenda-developments to date and the WTO 2017 Ministerial Conference in Buenos Aires.

seven proposals is shown in the working document in the form of open paragraphs with diverse alternatives on the definitions of overfished stocks. Most prominently, the European proposal and the texts from the ACP and LDC groups brought similar language on the determination of overfished stocks as dependent on National Authorities and Regional Fisheries Management Organizations. The joint proposal from New Zealand, Iceland and Pakistan claimed to define a stock as overfished when the necessity of reduction of mortality levels is needed to rebuild sustainable yields. This parameter was also found in the joint proposal by Argentina, Colombia, Peru, Costa Rica, Panama and Uruguay.

\section{Conclusion}

The long dated discussions over the environmental and developmental aspects of fisheries subsidies is still a center of divergences. The scope, the definitions and the determination of subsidies resulting in a diversity of practices affecting the fishing industry have been questioned since the 1990s in WTO fora. The necessity of technical cooperation and special and differentiated treatments to developing and least developed countries is acknowledged without a consensual line. A task that would sound as simple as to define "harmful subsidies" touches delicate aspects. For example on the understanding of subsidies designated to "vessels' capacity". If on the one side it can be understood as a harmful subsidy, as done so by the European Union, on the other side subsidies for capacity building that target safety measures, for instance, are not understood as harmful by others members.

Considering these and other difficulties, the WTO $11^{\text {th }}$ Ministerial Conference was unable to witness an agreement to discipline fisheries subsidies. As introduced, the "housepeeking Conference" merely produced a commitment from the member States to reach an agreement by 2019 on the MC12, in Jamaica ${ }^{37}$. The "agreement on disagreement" frustrated not just those expecting a text deliberating on IUU but added another level of preoccupation concerning the political will of members to eliminate support programmes for fisheries. The second paragraph of the document WT/MIN(17)/64 recalls that fisheries subsidies are under the umbrella of the Agreement on Subsidies and Countervailling Measures contrarily to the Agreement on

\footnotetext{
${ }^{37}$ WT/MIN(17)/64 (18 December 2017). Accessed on 22/12/2017
}

Revista Brasileira de Políticas Públicas e Internacionais, v.4, n.1, julho/2019, pp. 48-57. 
CAPUZZI, Bruno. The context of fisheries subsidies within the trade agenda-developments to date and the WTO 2017 Ministerial Conference in Buenos Aires.

Agriculture (AoA) and being one of the "unfinished businesses" from the Uruguay Round, as already described herein. If subjected to the provisions of the (AoA), the matter would have been affected by decisions from Nairobi $\left(\mathrm{MC}^{38}{ }^{38}\right)$ to completely eliminate export subsidies by developed members and to do so by 2018 by developing partners.

The FAO International Plan of Action to Prevent, Deter and Eliminate IUU also seems to be an intersection point from the July proposals. In reference to the working document 274, subsidies that result in fishing activities in overfished stocks might come as a realization of Buenos Aires if positions largely advance towards a bigger convergence during the conference.

Ultimately, if the modest advances on fisheries subsidies bring the expected results it might be a sole achievement of the conference projected to assume a housekeeping aspect. Nevertheless, even a modest bounding language on the prohibition of certain types of fisheries subsidies will symbolize an important common ground giving the overlapping jurisdiction of the Agreement on Subsidies and Countervailing Measures (SVM) and the Agreement on Agriculture (AoA). If a potential text brings clarification on whose prerogative will the management of fisheries be subjected to (if the FAO or the WTO) it shall be conceived as an extra bonus.

\section{References}

Bahety, S. Mukiibi, J. (2017). WTO fisheries subsidies Negotiations: Main Issues and Interests of Least Developed Countries. Geneva: Cuts International.

FAO - Food and Agriculture Organization of the United Nations (2016). The State of World Fisheries and Aquaculture: Contributing to Food Security and Nutrition for All. Rome: FAO.

Levi, M. Murphy, G. (2006). Coalitions of Contention: the case of the WTO Protests in Seattle. Hoboken: Blackwell Publishing.

Porter, G. (2002). Fisheries Subsidies and Overfishing: Towards a Structured Discussion. Geneva: UNEP.

UNCTAD - United Nations Conference on Trade and Development (2016). Trade and Environment Review 2016: Fish Trade. United Nations.

\footnotetext{
${ }^{38}$ WTO 10th Ministerial Conference, Nairobi 2015
}

Revista Brasileira de Políticas Públicas e Internacionais, v.4, n.1, julho/2019, pp. 48-57. 